\title{
Evaluation of Factors Affecting The Fungal Lipase Production Using One Factor at a Time Approach and Response Surface Methodology
}

\author{
Shimaa E. Helal", Hemmat M. Abdelhady*, Khadiga A. Abou-Taleb*, Mervat G. \\ Hassan and Mahmoud M. Amer \\ Department of Botany, Faculty of Science, Benha University, Benha-13518 and \\ *Department of Agricultural Microbiology, Faculty of Agriculture, Ain Shams \\ University, Cairo,Egypt.
}

\begin{abstract}
$\mathbf{T}$ HE CURRENT research deals with optimization of the factors affecting lipase production under submerged culture system. The most efficient isolate R1 was identified depending on cultural and morphological characteristics together with $18 \mathrm{~S}$ rRNA sequence as Rhizopus oryzae. Using one variable at a time, the maximum lipase activity $(171.8 \mathrm{U} / \mathrm{mL})$ was recorded in the presence of $1 \%$ fish-frying oil, mixture of peptone and yeast extract at $\mathrm{pH} 5$ with $8 \% \mathrm{v} / \mathrm{v}$ of fungal inoculum after 4 days at $30^{\circ} \mathrm{C}$. The screening of the most significant factors using Plackett-Burman design revealed that among ten variables, four, i.e. incubation temperature, inoculum size, incubation period and agitation speed, affected significantly (p-values ranged from 0.003 to 0.049 ) on the lipase activity. Optimization by using response surface methodology (RSM) through central composite design (CCD) resulted in the highest predicted lipase activity $(216.2 \mathrm{U} / \mathrm{mL})$ in which fermentation medium was inoculated with $8 \%$ inoculum size and incubated at $28^{\circ} \mathrm{C}$ under agitation speed of $150 \mathrm{rpm}$ for 4 days.
\end{abstract}

Keywords:Lipase production, Rhizopus oryzae, 18S rRNA sequence, Screening, Response surface methodology.

\section{Introduciton}

Lipases act at the boundary surface between organic and aqueous phases, catalyzing the breakdown of emulsified esters such as triolein and tripalmitin to glycerol and long chain fatty acids (Nagarajan, 2012). Because lipases are versatile for synthesis and hydrolysis in addition to their enantioselective, chemo-selective, or regioselective catalysis, their effect on the enzyme biotechnology became more prominent.

A number of vital sectors such as biodiesel, food, oil, detergent, fine-chemical, and pharmaceutical industries utilized lipase to enhance the product quality (Freire \& Castilho, 2008 and Carvalho et al. 2015). Lipases represent a unique factor, as activators, for making aqueous and non-aqueous phase interface in food industries (Patil \& Mahajan, 2011). Commercial lipases can be produced from a variety of microorganisms such as bacteria, yeasts and filamentous fungi (Abada, 2008). The latter microbes are considered the best producers of such enzymes, since they mostly present extracellular activities, facilitating proteins extraction in supernatant liquid in many species, such as Geotrichum candidum, Aspergillus niger, Aspergillus oryzae, Rhizopus delemear and Penicillium cyclopium (Patil \& Mahajan 2011 and Bueno et al. 2014).

Utilization of agro-industrial wastes provides an alternative source of substrates that may give a suitable solution of some pollution problems, which otherwise might be caused by their disposal. The origin and characteristics of the substrate (such as soybean, olive oil, or food industry by-products, as alternatives to reduce production costs) are the most important factors that directly affects fermentative processes for enzymes production (Salihu et al., 2012).

By contrast, the statistical optimization has many advantages over the classical technique of changing one variable at a time (Kaushik et al., 2006) such as lower number of experiments and the possibility of evaluating the interaction effects

\#Corresponding author email: shimaa.helal16@gmail.com 
among variables for the production of lipases by microorganisms (Teng \& Xu, 2008 and Wang et al., 2008). A facile screening of key variables for further optimization in a rational way can be achieved through Plackett-Burman design (PBD), an efficient and widely spread methodology (Rodrigues \& Iemma, 2014 and Vasiee et al. 2016).

The current study aimed to optimize the lipase production by a fungal strain using one variable at-a-time approach and statistical experimental designs.

\section{Materials and Methods}

\section{Isolation of lipolytic fungi}

Ten grams representative soil sample, which was collected from a gas station, Benha, Egypt, was suspended in $90 \mathrm{~mL}$ of sterilized water, shaken thoroughly for $10 \mathrm{~min}$ and left to settle for $5 \mathrm{~min}$. Fungal isolates were isolated from soil sample by spread plate technique on a potato-dextrose agar (PDA) medium (Difco Manual, 1998). The inoculated plates were incubated at $30^{\circ} \mathrm{C}$ for 7 days. The purified colonies were maintained at $5^{\circ} \mathrm{C}$ on agar slants for further studies.

\section{Screening the most potential lipolytic fungi}

Preselection of the efficient fungal isolates was performed using qualitative estimation, which depends on the use of chromogenic substrate. Fungal isolates were inoculated on agar plate medium supplemented with $1 \%$ olive oil and $0.01 \%$ phenol red as an indicator of oil degradation in agar (Singh et al., 2006). After incubation at $30^{\circ} \mathrm{C}$ for $72 \mathrm{~h}$, the isolates that exhibited the highest yellow zone were selected and submitted to submerged fermentation.

\section{Preparation of inoculum}

The fungal inoculum was prepared by scratching the spores of cultivated slants (108 spores $/ \mathrm{mL})$ into a medium consists of $(\mathrm{g} / \mathrm{L})$ : glucose, 10; peptone, 3; yeast extract, 2; $\mathrm{K}_{2} \mathrm{HPO}_{4}$, $2 ; \mathrm{MgSO}_{4} \cdot 7 \mathrm{H}_{2} \mathrm{O}, 1$; adjusted $\mathrm{pH}$ to 6.0 were used for submerged fermentation for one day.

\section{Submerged fermentation process}

The selected isolates were used for quantitative estimation through submerged fermentation. Erlenmeyer flasks $(250 \mathrm{~mL})$ containing $100 \mathrm{~mL}$ of fermentation medium (Prazeres et al., 2006) with the following composition $(\mathrm{g} / \mathrm{L})$ : olive oil, 10; peptone, 15; yeast extract, 5; $\mathrm{KH}_{2} \mathrm{PO}_{4}, 3$; $\mathrm{MgSO}_{4} .7 \mathrm{H}_{2} \mathrm{O}, 0.4$; adjusted $\mathrm{pH}$ to 6.0 were used for submerged fermentation. The flasks were inoculated with $5 \% \mathrm{v} / \mathrm{v}(108$ spores $/ \mathrm{mL})$ of tested isolates and incubated at $30^{\circ} \mathrm{C}$ on rotary shaker $(100 \mathrm{rpm})$ for $72 \mathrm{~h}$. At the end of incubation period, the fermented medium was filtrated using Whatman no. 1 filter paper, and then lipase activity was assayed in the supernatant. Triplicates of all experiments were done to assure the results.

\section{Identification of the most efficient isolate}

The most efficient fungal isolate R1 was identified based on phenotypic (Sutton et al., 1998) and confirmed by $18 \mathrm{~S}$ rRNA sequencing (genotypic identification) with the help of Solgent Company, Daejeon South Korea. Sequences were further analyzed using Basic Local Alignment Search Tool (BLAST) from the National Center of Biotechnology Information (NCBI) website (http://www.ncbi.nlm.nih.gov),(Knudsen et al., 2009).

Optimization of fermentation medium using one factor at-a-time method

\section{Fermentation period}

The most efficient strain was allowed to grow on the productive medium for different incubation periods ranging from one to 7 days on a rotary shaker $(100 \mathrm{rpm})$ at $30^{\circ} \mathrm{C}$.

\section{Nutritional factors}

Various carbon and nitrogen sources were applied to examine their effect on lipase production. The used carbon sources were fresh oils (olive oil, coconut oil, castor oil and crystal oil), waste oils (meat-frying oil, fishfrying oil, chicken-frying oil and potatoes-frying oil), margarine waste, butter waste and glucose. Six concentrations of the best carbon source (1, $2,4,6,8$ and $10 \%$ ) were applied to detect the optimum concentration for lipase production. Regarding the nitrogen sources experiments, the original nitrogen source (mixture of peptone and yeast extract) was replaced by organic nitrogen (peptone, yeast extract, beef extract, malt extract, tryptone \& urea) and inorganic nitrogen sources (ammonium oxalate, ammonium chloride, ammonium nitrate, ammonium sulphate, ammonium molybdate, sodium nitrate and potassium nitrate). For all nitrogen sources, the level of nitrogen was $2.8 \mathrm{~g} \mathrm{~N}$ per liter. 


\section{Cultural conditions}

Six levels of initial $\mathrm{pH}$ (3.0 to 8.0) and different degrees of incubation temperature $\left(20^{\circ} \mathrm{C}\right.$ to $\left.40^{\circ} \mathrm{C}\right)$ were tested for lipase production by the potential strain. Different sizes of standard inoculum ranged between 2 to $10 \mathrm{~mL}$ were studied.

Evaluation of the factors affecting lipase activity by statistical experimental designs

Screening of the most significant fermentation factors via Plackett-Burman Design (PBD)

PBD was used to evaluate the relative importance of nutritional and cultural conditions for lipase production by the pioneer strain (Plackett \& Burman, 1946), using the statistical software package Design-Expert 7.0.0 (Stat-Ease, Inc., Minneapolis, MN55413, 2005). Ten variables including 5 nutritional variables (fish-frying oil concentration as a sole carbon source, peptone, yeast extract concentration as nitrogen sources, $\mathrm{K}_{2} \mathrm{HPO}_{4}$ and $\mathrm{KH}_{2} \mathrm{PO}_{4}$ buffer concentrations) and 5 environmental variables $(\mathrm{pH}$, temperature, inoculum size, incubation period and agitation speed) with one dummy variable were screened for the tested fungi. All trials were performed in duplicate and the average of results was used as the response of the design. Each variable was represented at two levels; high and low, denoted by $(+)$ and (-) signs, respectively. PlackettBurman design was based on the first order model that was determined by equation 1 :

$$
\boldsymbol{Y}=\boldsymbol{B}_{\mathbf{0}}+\sum \boldsymbol{B}_{\boldsymbol{i}} \boldsymbol{X}_{\boldsymbol{i}}
$$

where $\mathrm{Y}$ is the predicted response (enzyme activity), B0 is model intercept and Bi represent variable estimates.

Effect of each variable was determined by equation (2):

$$
E\left(X_{i}\right)=2\left(\sum M_{i+}-\sum M_{i-}\right) / N
$$

where, $\mathrm{E}\left(\mathrm{X}_{\mathrm{i}}\right)$ is the tested variable effect, $\mathrm{M}_{\mathrm{i}^{+}}$and $M_{i-}$ represent enzyme production from trials in which the variable $\left(\mathrm{X}_{\mathrm{i}}\right)$ was present in high and low concentrations, respectively, and $\mathrm{N}$ is the number of trials.

Central composite design (CCD) and response surface methodology (RSM)

After identifying the significant variables for lipase production by tested fungi through PBD, a central composite design (CCD) was adopted to optimize the major variables. The four selected independent variables were studied at three different levels $(-1,0$ and +1$)$ and sets of 30 experiments (batch experiments) were carried out for the tested fungi including 6 trails have the same conditions represent the center points. The optimal values of the independent variables were calculated by maximizing equation 3 within a definite boundary condition. A multiple regression analysis of the data was performed and the relationship between the independent variables and the measured response was calculated by the second order polynomial equation 3.

$$
Y=B_{k 0}+\sum_{i=1}^{4} B_{k i} x_{i}+\sum_{i=1}^{4} B_{k i i} x_{i}^{2}+\sum_{i<i=2}^{4} B_{k i j} x_{i} x_{j}
$$

where $\mathrm{Y}$ is the predicted response; and are the coded independent variables; is the offset term; , and represent the regression coefficients.

Analysis of variance (ANOVA) through Fisher test was used to evaluate the effect of independent variables on the response and the significant results were identified by a $\mathrm{p}$-value of less than 0.05 . Multiple correlation coefficient ( $\mathrm{r}$ ) and adjusted $\mathrm{R}^{2}$ were used as quality indicators to evaluate the fitness of the second order polynomial equation. 3D response surface curves were employed to demonstrate interaction between the coded variables and the response. The optimal points were determined by solving the equation derived from the final quadratic model.

\section{Enzyme assay}

Copper soap method was used for the quantitative assay of lipase activity (Veerapagu et al., 2013) through colorimetric quantification of the liberated free fatty acids during hydrolysis of olive oil. The reaction mixture includes 1 $\mathrm{mL}$ of crude enzyme and $2.5 \mathrm{~mL}$ of olive oil (substrate) was incubated for $5 \mathrm{~min}$ at $37^{\circ} \mathrm{C}$. To cease the enzymatic reaction, $1 \mathrm{~mL}$ of $6 \mathrm{~N} \mathrm{HCl}$ and $5 \mathrm{~mL}$ of benzene was added. The upper layer $(4 \mathrm{~mL})$ was pipetted out into a test tube and $1 \mathrm{~mL}$ of cupric acetate-pyridine reagent was added. The free fatty acids (FFA) dissolved in benzene, yielding a blue color, was determined by measuring the absorbance of the solution at 715 $\mathrm{nm}$ using visible spectrophotometer (AZZOTA SV110 Digital Visible Spectrophotometer New Jersey USA). Lipase activity was determined by measuring the amount of FFA from the standard curve of oleic acid. One unit of lipase activity is defined as the amount of enzyme that liberates one $\mu$ mole of FFA in $1 \mathrm{~min}$ at $37^{\circ} \mathrm{C}$. 
Statistical analysis

The collected data were statistically analyzed using IBM ${ }^{\circledR}$ SPSS ${ }^{\circledR}$ Statistics software version 23.0 (2015) and the correlation coefficient was analyzed with Microsoft Office Excel 2013.

\section{$\underline{\text { Results and Discussion }}$}

\section{Isolation and screening of lipolytic fungi}

The results obtained from screening 74 fungal isolates on solid medium proved their ability of lipase production and they could be classified into three categories; weak (9-30 mm), moderate (31-50 mm) and high (51-80 mm) according to lipolytic activity on agar plates. The results of zone diameter obtained by fungal isolates of the third category (30 isolates) were depicted in Table 1. The highest halo zone on agar plates being $80 \mathrm{~mm}$ was achieved by both isolates $\mathrm{R} 1$ and AS11. The thirty isolates were cultivated in liquid medium and recorded lipase activities ranged between 10.3 and $70.8 \mathrm{U} / \mathrm{mL}$ after $72 \mathrm{~h}$ at $30^{\circ} \mathrm{C}$ using shake flasks as batch culture. The highest activity was obtained by isolate $\mathrm{R} 1$ being $70.8 \mathrm{U} / \mathrm{mL}$ followed by AS11 isolate $(34.3 \mathrm{U} / \mathrm{mL})$ and AS24 $(18.0 \mathrm{U} / \mathrm{mL})$, (Table 1). One way ANOVA test (analysis of variance) and means of difference by Duncan indicated that isolate R1 was statistically more significant $(\mathrm{p}<0.05)$ than other isolates in hydrolysis of olive oil. Therefore, the isolate R1 was used in further experiments.

Colen et al. (2006) obtained 59 fungal isolates producing-lipase, 11 isolates showed the highest clear zone. Candida gleesporioides was the best strain, which gave $14 \mathrm{~mm}$ of halo zone diameter, and $18.8 \mathrm{U} / \mathrm{mL}$ in liquid medium after 3 days using olive oil as substrate. In addition, Mohan et al. (2008) isolated twenty-eight isolates from coconut oil soil and selected five, which gave high lipase activities. Willerding et al. (2011) observed that among 181 strains, 75 strains (41\%) were found to have high ability for lipase production up to 72 hours of incubation period. Whereas, Oliveira et al. (2014) collected 23 lipolytic isolates from different sources; 7 isolates taken from residential grease trap, and 16 isolated from sewage treatment plant. Lipase activity for the potent one was $81.99 \mathrm{U} / \mathrm{L}$

\section{Identification of the most efficient lipolytic isolate}

According to Barnett \& Hunter (1998), the fungal isolate R1 was classified to the genus Rhizopus. (Fig. 1a). The NCBI database showed the highest percentage of similarity being $100 \%$ of the fungal isolate R1 with Rhizopus oryzae isolate VPCI 220/P/11 18S ribosomal RNA gene, partial sequence (accession number: KJ417560) as shown in Fig. 1b.

Optimization of fermentation medium using one factor at-a-time method

Time course of lipase activity

Niaz et al. (2014) stated that the incubation period is an important parameter for lipase production from different microorganisms. Results illustrated by Fig. 2 showed the extracellular lipase activity during fermentation period. It was observed that the best period, which attained the highest activity, was between the third and the fifth day (log phase) and gave the maximum peak after 4 days being $91.8 \mathrm{U} / \mathrm{mL}$ and then started to decrease. The specific lipase production rate was 0.27 /day after the first 4 days and the correlation coefficient ( $r$ ) between incubation period and enzyme activity was positive $(\mathrm{r}=0.43)$.

TABLE 1. Qualitative and quantitative estimations of the extracellular lipolytic activity by different fungal isolates after $72 \mathrm{~h}$ at $30^{\circ} \mathrm{C}$

\begin{tabular}{|c|c|c|c|c|c|c|c|c|}
\hline $\begin{array}{l}\text { Isolate } \\
\text { code }\end{array}$ & $\begin{array}{c}\text { Zone } \\
\text { diameter } \\
(\mathrm{mm})\end{array}$ & $\begin{array}{r}\text { Activity } \\
(\mathrm{U} / \mathrm{mL})\end{array}$ & $\begin{array}{l}\text { Isolate } \\
\text { code }\end{array}$ & $\begin{array}{c}\text { Zone } \\
\text { diameter } \\
(\mathrm{mm})\end{array}$ & $\begin{array}{l}\text { Activity } \\
\text { (U/mL) }\end{array}$ & $\begin{array}{l}\text { Isolate } \\
\text { code }\end{array}$ & $\begin{array}{c}\text { Zone } \\
\text { diameter } \\
(\mathrm{mm})\end{array}$ & $\begin{array}{c}\text { Activity (U/ } \\
\text { mL) }\end{array}$ \\
\hline $\mathrm{R} 1$ & $80^{\mathrm{a}}$ & $70.8^{\mathrm{a}}$ & AS13 & $54^{g}$ & $11.5^{\mathrm{q}, \mathrm{r}}$ & AS26 & $52^{\mathrm{h}}$ & $11.3^{\mathrm{q}, \mathrm{r}, \mathrm{s}}$ \\
\hline AS1 & $57^{\mathrm{f}}$ & $10.7^{\mathrm{s}, \mathrm{t}}$ & AS 14 & $75^{b}$ & $13.3^{\mathrm{m}, \mathrm{n}}$ & AS28 & $65^{\mathrm{d}}$ & $10.3^{\mathrm{t}}$ \\
\hline AS2 & $67^{d}$ & $16.2^{\mathrm{f}, \mathrm{g}}$ & AS 15 & $75^{\mathrm{b}}$ & $17.2^{\mathrm{d}, \mathrm{e}}$ & AS29 & $75^{\mathrm{b}}$ & $15.1^{\mathrm{h}, \mathrm{i}, \mathrm{j}}$ \\
\hline AS4 & $67^{d}$ & $12.5^{p}$ & AS 16 & $75^{\mathrm{b}}$ & $16^{\mathrm{f}, \mathrm{g}}$ & AS32 & $61^{\mathrm{e}}$ & $13.9^{1, \mathrm{~m}}$ \\
\hline AS5 & $75^{b}$ & $16.6^{\mathrm{e}, \mathrm{f}}$ & AS 17 & $53^{g}$ & $11.3^{\mathrm{q}, \mathrm{r}, \mathrm{s}}$ & AS33 & $75^{\mathrm{b}}$ & $15.1^{\mathrm{h}, \mathrm{i}, \mathrm{j}}$ \\
\hline AS7 & $75^{b}$ & $17.5^{\mathrm{d}}$ & AS 18 & $75^{b}$ & $15.2^{\mathrm{h}, \mathrm{i}, \mathrm{j}}$ & AS34 & $65^{\mathrm{d}}$ & $11.8^{\mathrm{q}}$ \\
\hline AS8 & $61^{\mathrm{e}}$ & $11^{\mathrm{r}, \mathrm{s}}$ & AS21 & $75^{b}$ & $14.6^{\mathrm{j}, \mathrm{k}}$ & AS35 & $57^{\mathrm{f}}$ & $15^{\mathrm{i}, \mathrm{j}}$ \\
\hline AS9 & $65^{d}$ & $13.1^{\mathrm{n}, \mathrm{o}, \mathrm{p}}$ & AS23 & $58^{\mathrm{f}}$ & $12.6^{\mathrm{o}, \mathrm{p}}$ & AS36 & $75^{\mathrm{b}}$ & $13.2^{\mathrm{n}, \mathrm{o}}$ \\
\hline AS 10 & $70^{c}$ & $15.6^{\mathrm{g}, \mathrm{h}, \mathrm{i}}$ & AS24 & $76^{\mathrm{b}}$ & $18.6^{c}$ & AS37 & $75^{\mathrm{b}}$ & $15.8^{\mathrm{g}, \mathrm{h}}$ \\
\hline AS11 & $80^{\mathrm{a}}$ & $34.3^{\mathrm{b}}$ & AS25 & $75^{b}$ & $16.5^{\mathrm{f}}$ & AS38 & $75^{\mathrm{b}}$ & $14.3^{\mathrm{k}, 1}$ \\
\hline
\end{tabular}

Values in the same column (followed by letters with aliphatic series) sharing the same letters do not differ significantly whereas the values followed letters in different alphabetic series are significantly different according to Duncan (1955) at $5 \%$ level. 
a)
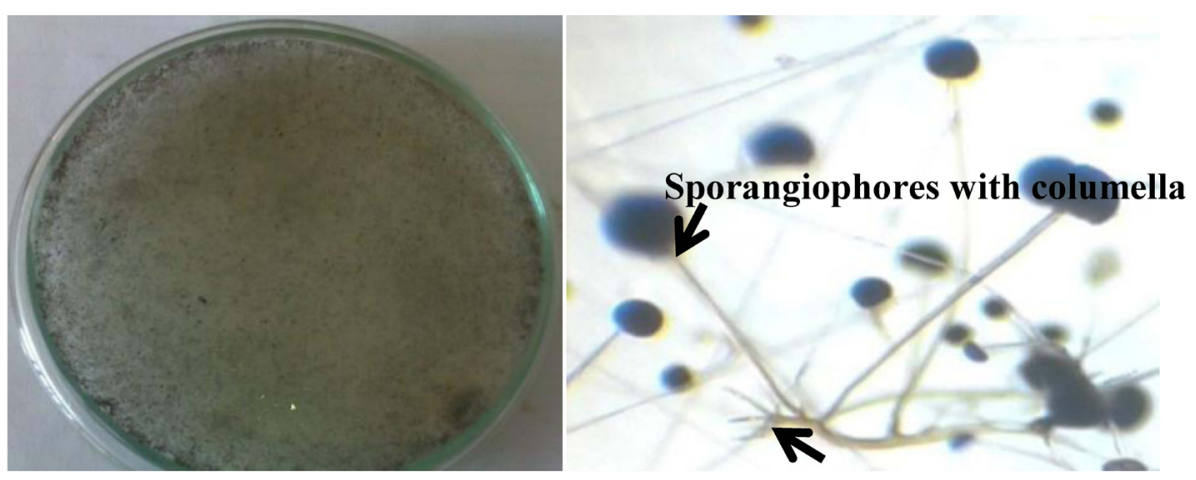

Brownish rhizoids

- Rhizopus oryzae isolate VPCI 1100/11 (KJ417533)

b) 99 Rhizopus oryzae strain CNRMA 03.253 (DQ119029)

99 Rhizopus oryzae strain CNRMA 04.160 (DQ119027)

100. Rhizopus oryzae strain JCM 12785 (AY803931)

- Rhizopus oryzae strain ATCC 11886 (AY803930)

${ }_{85} 100$ Rhizopus oryzae isolate VPCl 220/P/11 (KJ417560)

85. Unknown isolate R1

90: Rhizopus oryzae isolate VPCI 1157/10(KJ417538)

100 Rhizopus oryzae isolate VPCI 1151/10(KJ417536)

Rhizopus oryzae isolate VPCl 11
93. Rhizopus oryzae strain CBS 126971 (KJ744361)

95. Rhizopus oryzae strain WM 06.833 isolate ISHAM-ITS_ID MITS3003 (KP068977)

95. Rhizopus oryzae isolate VPCI 145/P/10 (KJ417558)

Rhizopus oryzae isolate VPCI 2147/11|(KJ417556)

- Rhizopus oryzae isolate VPCI 844/11 (KJ417555)

- Rhizopus oryzae isolate VPCI 1980/11 (KJ417549) 0.400

Fig. 1. Identification of fungal isolate R1 based on a) phenotypic characteristics, and b) genotypic characteristics: the phylogenetic tree was based on the 18S rRNA gene sequences of Rhizopus sp. $\mathrm{R} 1$ and related species of the genus Rhizopus.

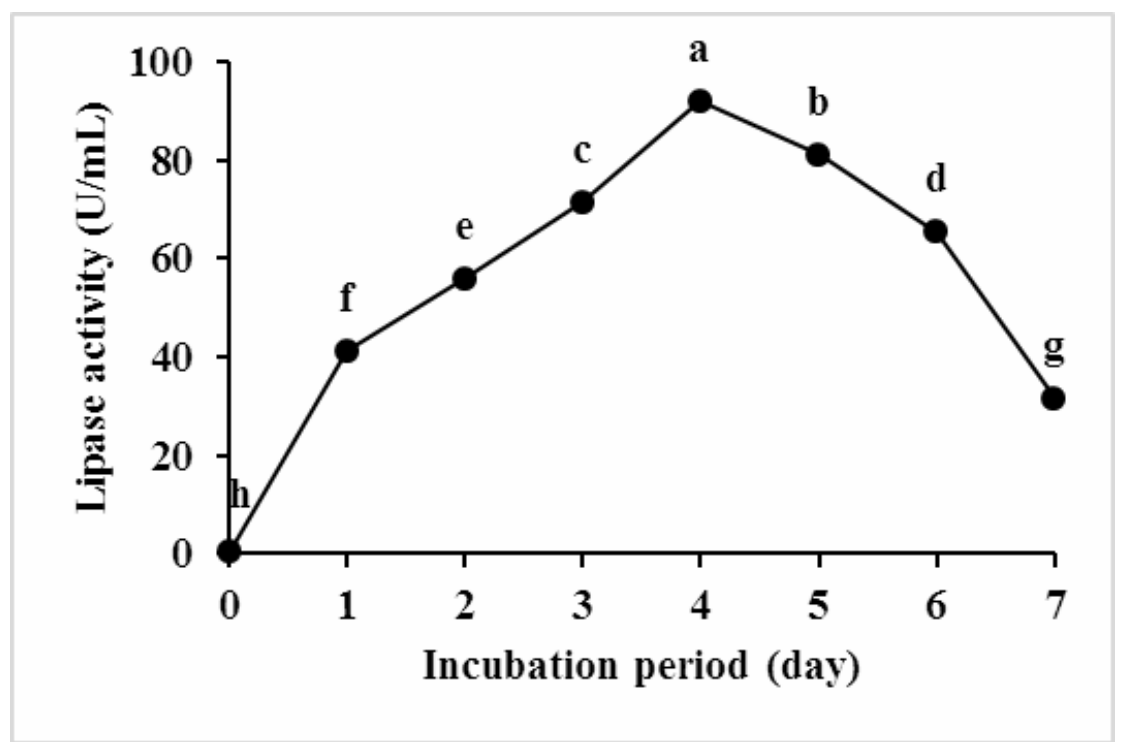

Values sharing the same letters do not differ significantly whereas those followed letters in different alphabetic series are significantly different according to Duncan (1955) at $5 \%$ level.

Fig. 2. Effect of incubation period on lipase activity by $R$. oryzae R1. 
These results agree well with Imandi et al. (2013) who revealed that the highest activity of lipase produced by Yarrowia lipolytica as achieved on the fourth day and the subsequent decrease in activity may be due to metabolism changes such as nutrition consumption, change in $\mathrm{pH}$ or final products accumulation. In addition, Rodrigues et al. (2015) recorded that the most efficient isolate gave the highest lipase activity after 5 days of incubation period in mineral media.

Therefore, the fermentation time of 4 days was considered in the further studies for lipase production by $R$. oryzae $\mathrm{R} 1$ strain.

\section{Effect of carbon source}

The effect of carbon sources on lipase activity by $R$. oryzae R1 strain was illustrated by Fig. 3a. Maximum lipase activity was recorded in the presence of fish-frying oil $(128.0 \mathrm{U} / \mathrm{mL})$ followed by meat-frying oil $(110.0 \mathrm{U} / \mathrm{mL})$, which might be due to lipases are inducible enzymes, secreted in media when stimulated with specific (lipid) substrate (Colak et al., 2007). The catabolite repression (Kiran et al., 2008), which took place by using glucose as carbon source is responsible for minimization in lipase activity $(43.1 \mathrm{U} / \mathrm{mL})$.

The statistical analysis indicated that medium supplemented with fish-frying oil or meat-frying oil as a sole carbon sources has high significant effect on lipase production by $R$. oryzae R 1 comparing to other carbon sources, which increased about $39.1 \%$ or $19.6 \%$, relative to olive oil (control), respectively.

Using different concentrations of meat-frying oil (1-10\%) demonstrated that $2 \%$ achieved the highest activity $(118.0 \mathrm{U} / \mathrm{mL})$. Whereas, regarding fish-frying oil, the upmost activity $(128.0 \mathrm{U} / \mathrm{mL})$ was noticed at $1 \%$ of the oil concentration. Changing the oil concentration rather than the optimum value led to a decrease in lipase production. The correlation coefficient (r) between meat-frying oil concentration and enzyme activity was -0.93 .

Such results are in a good accordance with Morais et al. (1998) who reported that the lipase activity decreased with increasing the concentration of soybean oil for Aspergillus oryzae. Also, Maia et al. (1999) recorded that the maximum activity of lipase was obtained in a medium supplemented with $1 \%$ olive oil, which increased about 8 -fold than basal medium as control.

Stimulation of lipase activity was related not only to the length of carbon chains of fatty acids and degree of unsaturation but also to the substrate concentration (Lima et al., 2003). In addition, Falony et al. (2006) revealed that $A$.

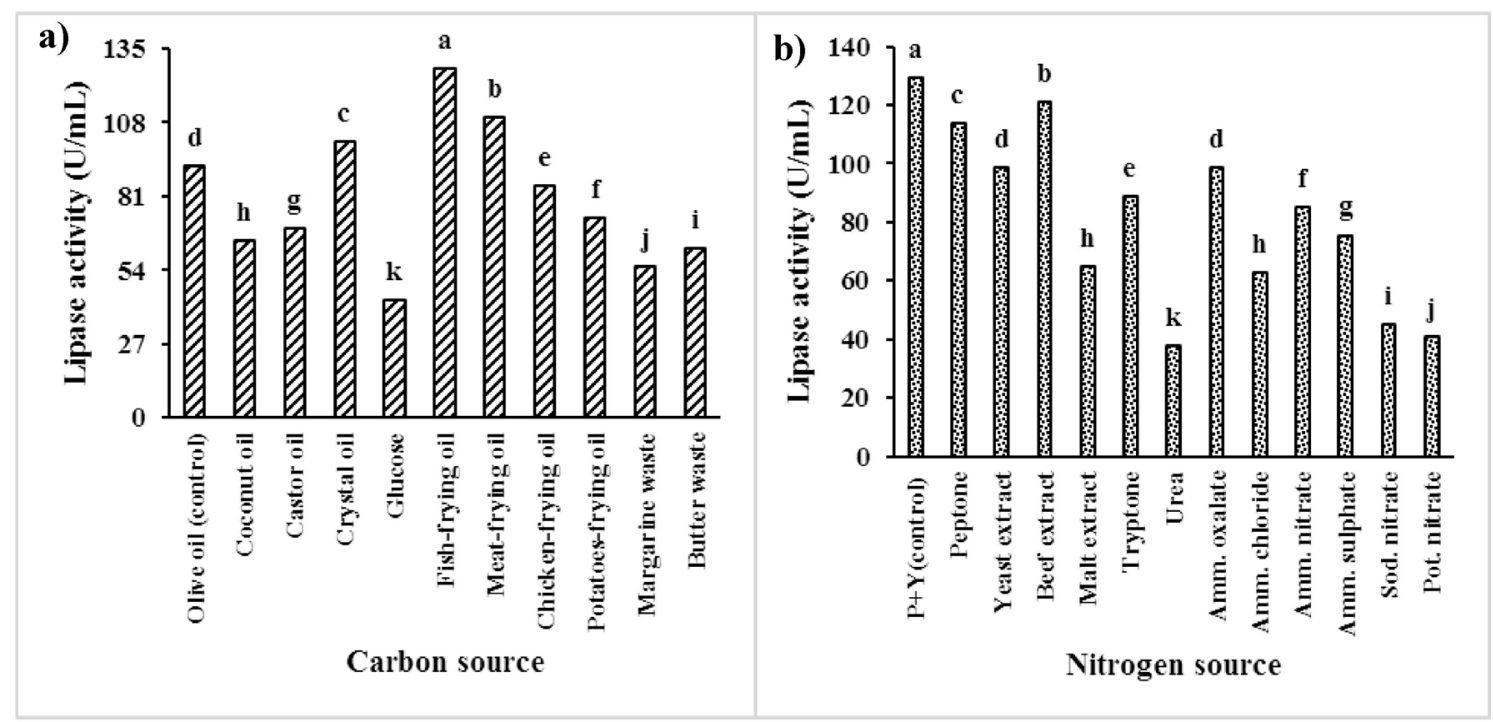

Values sharing the same letters do not differ significantly whereas those followed letters in different alphabetic series are significantly different according to Duncan (1955) at 5\% level.

Fig. 3. Lipase activity as influenced by nutritional factors of $\mathrm{R}$. oryzae $\mathrm{R} 1$ after 4 days at $30 \mathrm{C}$ using shake flaks as a batch culture. a) Different carbon sources, b) Different nitrogen sources. $P=$ peptone, $Y=$ yeast extract, Amm.=Ammonium, Sod. $=$ Sodium, Pot. $=$ Potassium 
niger preferred sugar substrates (glucose) only for fungal growth but not for lipase production. Reshma \& Shanmugam (2013) used different substrates as carbon source namely; olive oil, refined oil, rice bran oil, gingelly oil and leather fleshing oil. It was observed that the lipase activity ranged from 140 to $165 \mathrm{U} / \mathrm{mL}$ and increasing the concentration of the oil decreases the activity.

Generally, it could be stated that $1 \%$ fish frying oil was the best carbon source concentration for lipase production by $R$. oryzae R1.

\section{Effect of nitrogen source}

The influence of different organic and inorganic nitrogen sources on lipase activity of tested strain indicated that organic nitrogen sources furnished better results than the inorganic ones. This was explained by Böhm \& Boos (2004) who stated that inorganic nitrogen sources are consumed quickly and normally cause repression of enzyme synthesis while organic nitrogen sources can supply amino acids, and many cell growth factors, which are needed for cell metabolism and protein synthesis.

Figure $3 \mathrm{~b}$ exhibited that the highest enzyme activity was noticed on a medium supplemented with a mixture of peptone and yeast extract $(129.5 \mathrm{U} / \mathrm{mL})$ followed by beef extract $(121.3$ $\mathrm{U} / \mathrm{mL}$ ). When peptone and yeast extract mixture was replaced by individual nitrogen sources, the lipolytic activity decreased to $38.0 \mathrm{U} / \mathrm{mL}$ on a medium containing urea as nitrogen source. Whereas, in case of ammonium molybdate, $R$. oryzae R1 strain lost the enzyme activity completely (not detected). In addition, ammonium oxalate was the best inorganic nitrogen source for lipase activity being $98.8 \mathrm{U} / \mathrm{mL}$.

The results agree well with Supakdamrongkul et al. (2010) who reported that the upmost yield of lipase was recorded in a medium containing organic nitrogen sources by various microorganisms. Also, Ulker et al. (2010) revealed that peptone was the best nitrogen source for lipase activity by a novel strain of Trichoderma harzianum IDMMD, whereas the enzyme activity was decreased when the strain was cultivated in a medium containing yeast extract. However, Roveda et al. (2010) observed that sodium nitrate was the best nitrogen source for lipase production.

\section{Effect of initial $p H$}

Results visualized in Fig. 4a demonstrated that the lipase production by $R$. oryzae $\mathrm{R} 1$ has a significant difference $(\mathrm{p}<0.05)$ at different $\mathrm{pH}$ levels ranged from 3 to 8 . High values of lipase activity were observed at $\mathrm{pH}$ range from 4 to 6 . The maximum enzyme activity $(141.6 \mathrm{U} / \mathrm{mL})$ was achieved at $\mathrm{pH} 5$, the most favorable one, and the activity increased about 1.09-fold if compared to its value in control ( $\mathrm{pH} \mathrm{6).} \mathrm{An} \mathrm{appropriate}$ interpretation for the sudden drop in lipase activity at $\mathrm{pH} 8$ is that initial basic medium could enhance intracellular $\mathrm{pH}$ of the cells and destabilize the enzyme synthetic network (Stockar et al., 2006). The correlation coefficient between initial $\mathrm{pH}$ and enzyme activity was -0.61 .

These results are in a good agreement with those given by Dia \& Xia (2008) who showed that maximum lipase production by Pencillium expansum was at initial $\mathrm{pH}$ 5.5-6.0. Huang et al. (2009) recorded that the highest lipase production from Metarhizium anisopliae was at pH 5.7.

By contrast, Colin et al. (2010) revealed that the initial $\mathrm{pH} 7$ was the best level for lipase production by $A$. niger, which increased about 1.4fold as compared to that in basal medium adjusted to $\mathrm{pH}$ 5.0. Also, Kakde (2011) observed that the upmost lipase activity was achieved at $\mathrm{pH}$ ranged from 6.5 to 7.5 by Fusarium oxysporum.

\section{Effect of incubation temperature}

Lipase production by $R$. oryzae $\mathrm{R} 1$ as influenced by different incubation temperature was shown in Fig. 4b. The optimum temperature for lipase production was determined at $30^{\circ} \mathrm{C}$ with activity of $142.8 \mathrm{U} / \mathrm{mL}$. A drastic decline in activity at $40{ }^{\circ} \mathrm{C}$ being $83.7 \mathrm{U} / \mathrm{mL}$ is $41.4 \%$ lower than its value at optimal temperature. This may be explained by the denaturation of the enzyme protein tertiary structure by excessive heat (Gomes et al., 2006). Similar results were reported by Kakde (2011) in which F. oxysporum gave maximum activity of lipase at $30 \mathrm{C}$. Whereas, Colin et al. (2010) found maximum lipase activity by A. niger M4A 135 at $37^{\circ} \mathrm{C}$ which increased to 4.3 and 3.2 -fold if compared to its value at $25^{\circ} \mathrm{C}$ and $30^{\circ} \mathrm{C}$, respectively.

\section{Effect of inoculum size}

Fig. $4 \mathrm{c}$ indicated that the lipase activity gradually increased with increasing the inoculum size up to $8 \% \mathrm{v} / \mathrm{v}$ that gave the maximum activity 

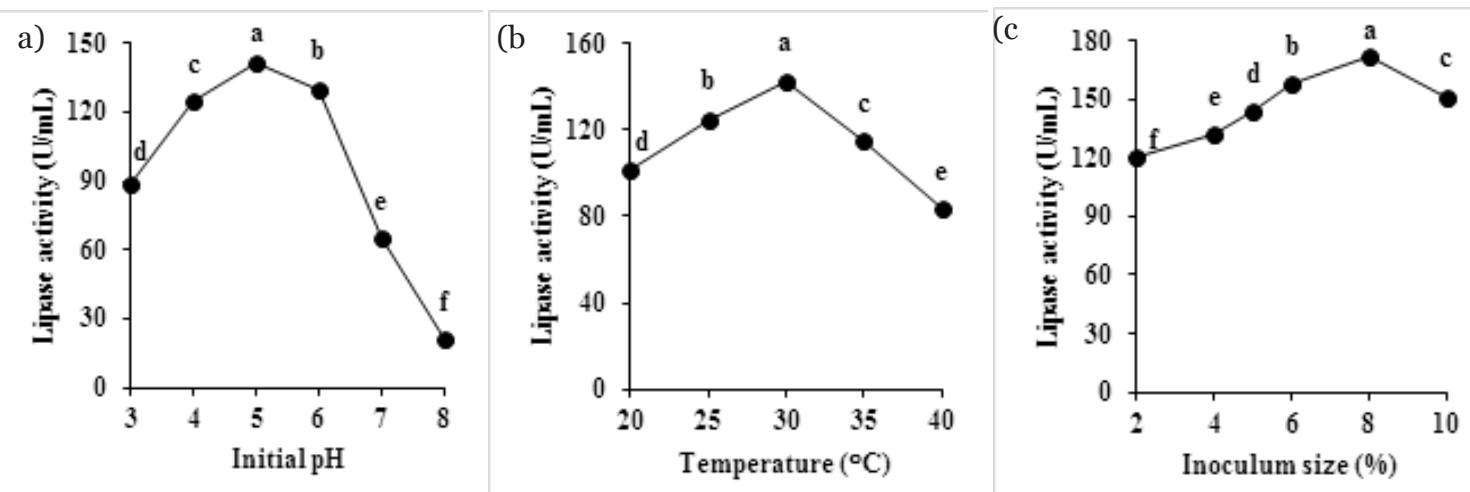

Values sharing the same letters do not differ significantly whereas those followed letters in different alphabetic series are significantly different according to Duncan (1955) at 5\% level.

Fig. 4. Lipase production by $R$. oryzae $\mathrm{R} 1$ as influenced by environmental conditions: a) Initial pH, b) Incubation temperature, and c) Inoculum size.

$(171.8 \mathrm{U} / \mathrm{mL})$. Increasing the inoculum size than $8 \% \mathrm{v} / \mathrm{v}$ decreases the lipase production. This may be due to enhancement in cell mass formation and exhaustion of nutrients (Iftikhar et al. 2008). Correlation coefficient $(\mathrm{r})$ was highly positive $(\mathrm{r}=$ 0.78). On the other hand, Prabhakar et al. (2002) found that $10 \%$ inoculum size of $A$. japonicus was favorable for maximum lipase activity.

Statistical experimental designs for evaluation of the factors affecting lipase activity

Screening of the most significant fermentation factors using Plackett-Burman design

Plackett-Burman statistical method was performed to screen out the positive factors contributing to the lipase production by $R$. oryzae $\mathrm{R} 1$. Based on Table 2, a wide variation in lipase activity was observed from 68.1 to $211.0 \mathrm{U} / \mathrm{mL}$ in twelve experiments due to the influence of interactions between variables. Maximal lipase activities (211.0 and $198.3 \mathrm{U} / \mathrm{mL})$ were achieved at runs number 9 and 11, respectively. These runs ( $9 \& 11)$ have the optimum conditions for lipase production such as temperature $\left(29^{\circ} \mathrm{C}\right)$, inoculum size ( $8 \%$ ), incubation period (4 days) and agitation speed $(100 \mathrm{rpm})$. The lowest activity of lipase was observed in runs number $3,4,5,7,8$ and 10 . This may be due to the static condition that eliminates the proper growth of $R$. oryzae R1.

Analysis of variance of the PBD results was evaluated and presented in Table 3. The Model F-value of 12.4 implies that the model is significant for lipase activity and there is only a $1.4 \%$ chance that an F-value could occur due to noise. The analyzed data suggests that out of 10 different independent variables, only four (incubation temperature, inoculum size, incubation period and agitation speed) significantly affected the lipase activity which have $\mathrm{p}$-values ranged from 0.003 to 0.049 and the remainder factors were fixed in the next stage of optimization. The smaller p-value indicates the high significance of the corresponding coefficient (Tanyildizi et al., 2005). The coefficient of determination $\left(\mathrm{R}^{2}\right)$ was 0.96 that indicates a satisfactory representation of the process model and a high correlation between the experimental and predicted values.

Equation obtained for optimization by PBD (first order model) was as follows:

$$
\mathrm{Y}_{\text {lipase activity }}=+115.40-0.25(\mathrm{~A})-4.25(\mathrm{~B})
$$
$+21.90(\mathrm{C})+14.40(\mathrm{D})-13.38(\mathrm{E})+7.48(\mathrm{~F})-$ $3.42(\mathrm{G})+31.33(\mathrm{H})-8.23(\mathrm{~J})+6.85(\mathrm{~K})-5.13$ (L)

where $\mathrm{Y}$ is the predicted response

The pareto graph (Fig. 5) showed the percentage of the contribution (main effect) for eleven variables on the model which ranged from 0.01 to $47.32 \%$ for lipase. The four significant variables, $(\mathrm{C}, \mathrm{D}, \mathrm{E} \& \mathrm{H})$, have the highest contribution effect. The positive coefficients (blue bars) suggest an incremental effect on activity of lipase, while, negative coefficients (orange bars) imply a decremented effect on lipase activity. 
TABLE 2. Plackett-Burman experimental design matrix and the actual values of lipase activity by $R$. oryzae R1.

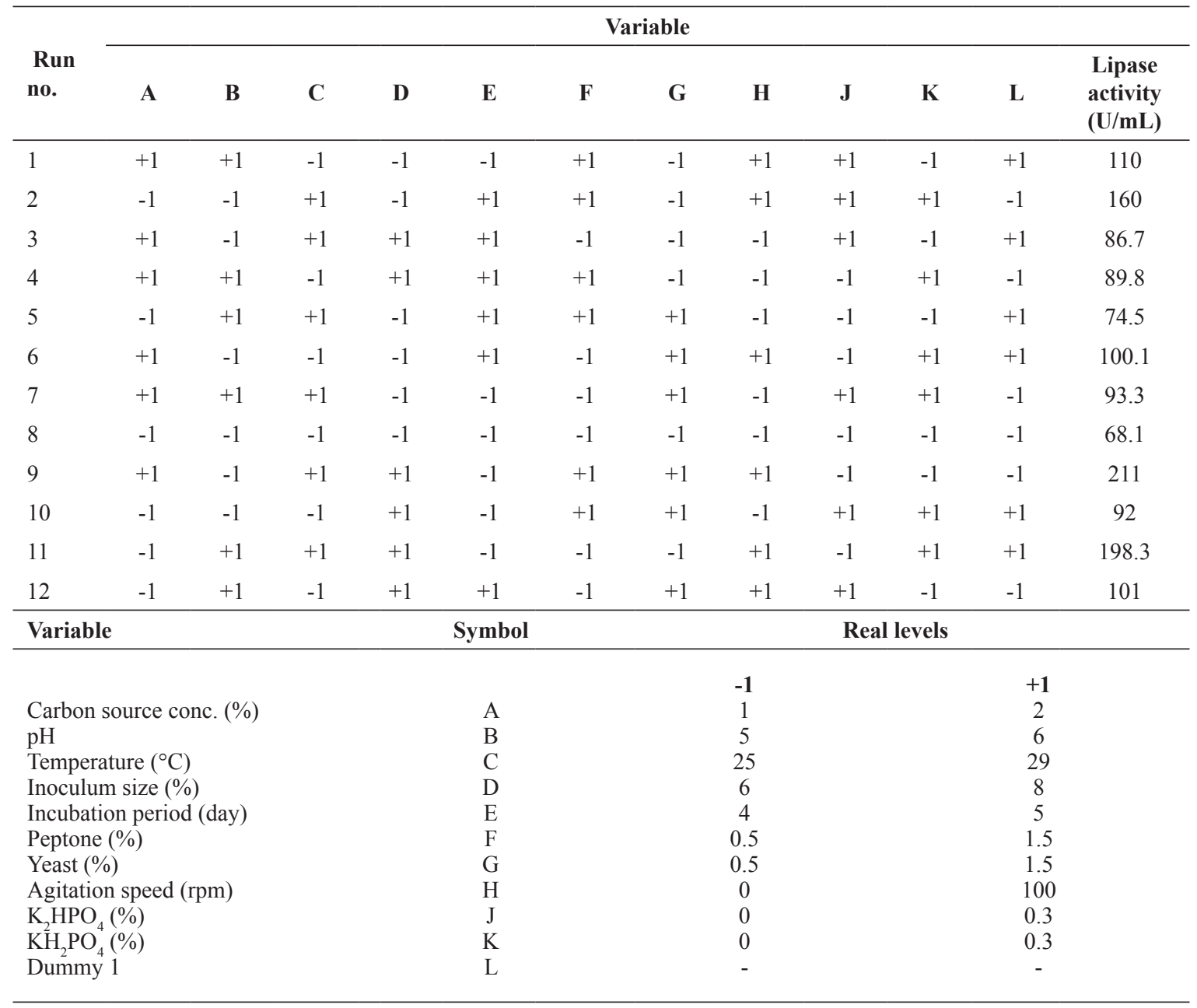

$A-K=$ Nutritional and physical variables, $L=$ Dummy variable, conc. $=$ concentration.

TABLE 3. Statistical analysis of variance (ANOVA) of Plackett-Burman design for lipase activity by R. oryzae R1.

\begin{tabular}{|c|c|c|c|c|c|}
\hline Variable & df & $\begin{array}{c}\text { Mean } \\
\text { Square }\end{array}$ & Coefficients & F-value & $\begin{array}{c}\text { p-value } \\
\text { Prob }>\text { F }\end{array}$ \\
\hline Model & 7 & 3399.98 & 115.4 & 12.4 & $0.0142 *$ \\
\hline A-Fish oil & 1 & 0.75 & -0.25 & 0.0007947 & 0.979 \\
\hline B-pH & 1 & 216.75 & -4.25 & 0.23 & 0.657 \\
\hline C-Incubation temperature & 1 & 5755.32 & 21.9 & 20.99 & $0.010^{*}$ \\
\hline D-Inoculum size & 1 & 2488.32 & 14.4 & 9.07 & $0.039^{*}$ \\
\hline E-Incubation period & 1 & 2149.36 & -13.38 & 7.84 & $0.049^{*}$ \\
\hline F-Peptone & 1 & 672 & 7.48 & 2.45 & 0.193 \\
\hline G-Yeast extract & 1 & 140.08 & -3.42 & 0.51 & 0.514 \\
\hline H-Agitation speed & 1 & 11781.3 & 31.33 & 42.97 & $0.003 *$ \\
\hline $\mathrm{J}-\mathrm{K}_{2} \mathrm{HPO}_{4}$ & 1 & 813.45 & -8.23 & 2.97 & 0.160 \\
\hline $\mathrm{K}-\mathrm{KH}_{2} \mathrm{PO}_{4}$ & 1 & 563.07 & 6.85 & 0.60 & 0.483 \\
\hline L-Dummy 1 & 1 & 316.21 & -5.13 & 0.34 & 0.594 \\
\hline Std. Dev. & \multicolumn{5}{|c|}{16.56} \\
\hline Mean & \multicolumn{5}{|c|}{115.40} \\
\hline 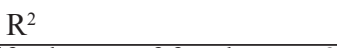 & \multicolumn{5}{|c|}{0.96} \\
\hline
\end{tabular}


These results are in a good agreement with Lima et al. (2003) who demonstrated that temperature $\left(29^{\circ} \mathrm{C}\right)$ had a significant effect and affected by $(98.9 \%)$ on the model. Likewise, Amin \& Bhatti (2014) mentioned that both incubation temperature and agitation had affected the fermentation process significantly $(\mathrm{p}<0.05)$ by Penicillium fellutanum, which plays a key role in the biochemical activities of microorganism. Moreover, Bueno et al. (2014) confirmed that the use of organic nitrogen source (corn steep liquor), carbon (soybean oil), magnesium ion $\left(\mathrm{MgSO}_{4} \cdot 7 \mathrm{H}_{2} \mathrm{O}\right)$ and potassium ion $\left(\mathrm{KH}_{2} \mathrm{PO}_{4}\right)$ had no significant effects $(\mathrm{p}>0.05)$ on the lipase production using Plackett-Burman design. On the contrary, Colla et al. (2016) confirmed that agitation speed has no significant influence ( $p$ $>0.1$ ) on lipase production by both Aspergillus niger and Aspergillus flavus.

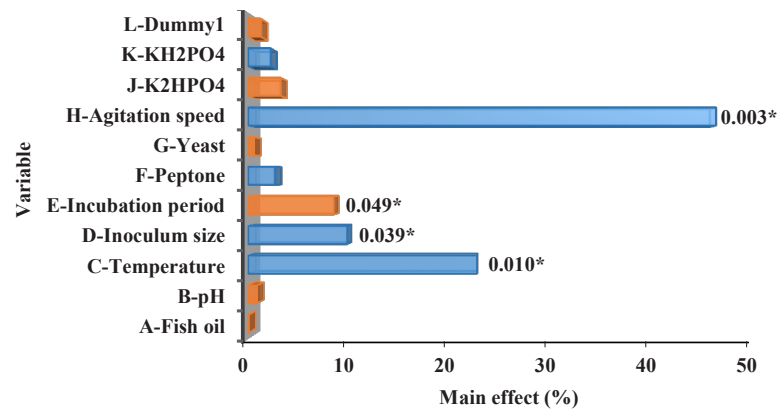

Fig. 5. Pareto graph showing the main effect (\%) of eleven variables on lipase activity by $R$. oryzae $\mathbf{R} 1$ and the corresponding p-values (number above bar) showing their significance. Blue bars indicate the positive effect and orange bars are negative effect.

Optimization by central composite design (CCD) and response surface methodology (RSM)

After selecting the most significant variables influencing lipase activity by $R$. oryzae $\mathrm{R} 1$, a central composite design (CCD) was performed to determine the optimal levels and the interactions among the selected significant variables. Table 4 exhibits the effects of four independent variables on lipase activity at three coded levels with actual and predicted response.

The maximum value $(215 \mathrm{U} / \mathrm{mL})$ was achieved in run number 21 at $28{ }^{\circ} \mathrm{C}$ with $8 \%$ inoculum size after 4 days under of $150 \mathrm{rpm}$ of agitation speed. High temperature and low incubation period were attributable to the lowest activity that was observed in run number 8 .

The statistical significance of the model was checked by F-test and ANOVA for the response surface quadratic model and the data summarized in Table 5. The model F-value of 1818.35 implied that the model was significant (p-value $<0.0001)$, which indicates that there was only a $0.01 \%$ chance that a "Model F-value" could occur because of noise. From the degree of significance, the linear coefficients variables (C), (D), (E), (H), interaction between two variables $(\mathrm{CE})$ and quadratic of variables $\left(\mathrm{D}^{2}\right.$, $\mathrm{E}^{2} \& \mathrm{H}^{2}$ ) significantly influenced the lipase activity. The determination coefficient $\mathrm{R}^{2}$ of the model was 0.99 that explained $99 \%$ of the total variations and revealed excellent agreement between the experimental and the predicted values.

Akhnazarova \& Kefarov (1982) stated that precision, accuracy and reliability of the model can be deduced from low values of coefficient of variation $(\mathrm{CV})$. Therefore, the value of such coefficient $(1.06 \%)$ of this model is perfect.

The mathematical model describing the relationship between variables $(\mathrm{C}, \mathrm{D}, \mathrm{E} \&$ $\mathrm{H})$ and response $(\mathrm{Y})$ for lipase activity could be obtained by the following second order polynomial equation:

$$
\begin{array}{r}
\mathrm{Y}_{\text {Lipase activity }}=+137.24-51.18(\mathrm{C})-3.02(\mathrm{D}) \\
+17.97(\mathrm{E})+4.59(\mathrm{H})-0.33(\mathrm{CD})-2.97(\mathrm{CE}) \\
+0.38(\mathrm{CH})-0.44(\mathrm{DE})-0.069(\mathrm{DH})+0.32 \\
(\mathrm{EH})+0.71\left(\mathrm{C}^{2}\right)+6.41\left(\mathrm{D}^{2}\right)+1.96\left(\mathrm{E}^{2}\right)-9.99
\end{array}
$$$$
\left(\mathrm{H}^{2}\right)
$$

Three-dimensional response surface plots explain the interaction among variables and each plot represents the effect of two factors while the others were held at optimum level, (Fig. 6). These plots indicated that the optimum conditions for the highest lipase activity were at $28^{\circ} \mathrm{C}, 8 \%$ inoculum size, 4 days under $125 \mathrm{rpm}$ of agitation speed. Variations in the optimum conditions led to decrease the lipase activity (yellow and green region). The vital difference between these plots is the p-value, which altered the shapes of $3 \mathrm{D}$ diagram. The highest significance effect afforded perfect interaction and more horizontal 3D surface (Tanyildizi et al., 2005). 
TABLE 4. Central composite design matrix of independent variables used in RSM studies and lipase activity (actual \& predicted values) by $R$. oryzae $\mathrm{R} 1$.

\begin{tabular}{|c|c|c|c|c|c|c|}
\hline \multirow{2}{*}{$\begin{array}{c}\text { Run } \\
\text { no. }\end{array}$} & \multicolumn{4}{|c|}{ Variable } & \multicolumn{2}{|c|}{ Lipase activity (U/mL) } \\
\hline & $\mathbf{C}$ & D & $\mathbf{E}$ & $\mathbf{H}$ & Actual & Predicted \\
\hline 1 & +1 & -1 & +1 & -1 & 97.8 & 98.59 \\
\hline 2 & +1 & +1 & +1 & +1 & 101.3 & 101.6 \\
\hline 3 & -1 & -1 & +1 & -1 & 207 & 207 \\
\hline 4 & 0 & 0 & 0 & 0 & 138.2 & 137.24 \\
\hline 5 & -1 & -1 & -1 & +1 & 173.3 & 172.8 \\
\hline 6 & -1 & +1 & -1 & +1 & 168.8 & 168.18 \\
\hline 7 & +1 & 0 & 0 & 0 & 85.2 & 86.87 \\
\hline 8 & +1 & +1 & -1 & -1 & 63.7 & 62.68 \\
\hline 9 & 0 & 0 & +1 & 0 & 158.3 & 157.17 \\
\hline 10 & -1 & +1 & +1 & -1 & 201 & 200.88 \\
\hline 11 & 0 & 0 & 0 & +1 & 131 & 131.85 \\
\hline 12 & 0 & 0 & 0 & 0 & 138.2 & 137.24 \\
\hline 13 & 0 & 0 & 0 & 0 & 138.2 & 137.24 \\
\hline 14 & +1 & +1 & +1 & -1 & 91.3 & 91.15 \\
\hline 15 & 0 & 0 & 0 & 0 & 138.2 & 137.24 \\
\hline 16 & +1 & -1 & +1 & +1 & 110 & 109.32 \\
\hline 17 & 0 & -1 & 0 & 0 & 147.2 & 146.67 \\
\hline 18 & +1 & -1 & -1 & -1 & 68.8 & 68.35 \\
\hline 19 & 0 & 0 & 0 & 0 & 138.2 & 137.24 \\
\hline 20 & +1 & -1 & -1 & +1 & 77.5 & 77.8 \\
\hline 21 & -1 & -1 & +1 & +1 & 215 & 216.2 \\
\hline 22 & 0 & +1 & 0 & 0 & 138.2 & 140.64 \\
\hline 23 & -1 & -1 & -1 & -1 & 165 & 164.8 \\
\hline 24 & -1 & +1 & -1 & -1 & 160.5 & 160.53 \\
\hline 25 & 0 & 0 & 0 & -1 & 121.6 & 122.6 \\
\hline 26 & -1 & +1 & +1 & +1 & 210 & 209.8 \\
\hline 27 & +1 & +1 & -1 & +1 & 72.5 & 71.85 \\
\hline 28 & 0 & 0 & 0 & 0 & 138.2 & 137.24 \\
\hline 29 & 0 & 0 & -1 & 0 & 118.2 & 121.24 \\
\hline 30 & -1 & 0 & 0 & 0 & 188.8 & 189.14 \\
\hline \multicolumn{2}{|c|}{ Variable } & \multicolumn{2}{|c|}{ Symbol } & \multicolumn{3}{|c|}{ Reallevels } \\
\hline \multirow{2}{*}{\multicolumn{2}{|c|}{ Temperature $\left({ }^{\circ} \mathrm{C}\right)$}} & \multirow{2}{*}{\multicolumn{2}{|c|}{$\mathrm{C}$}} & -1 & & +1 \\
\hline & & & & 28 & 31. & 35 \\
\hline \multicolumn{2}{|c|}{ Inoculum size $(\%)$} & \multicolumn{2}{|c|}{$\mathrm{D}$} & 8 & 9 & 10 \\
\hline \multicolumn{2}{|c|}{ Incubation period (day) } & \multicolumn{2}{|c|}{$\mathrm{E}$} & 2 & \multirow{2}{*}{$\begin{array}{r}3 \\
12\end{array}$} & 4 \\
\hline Agit & & \multicolumn{2}{|c|}{$\mathrm{H}$} & 100 & & 150 \\
\hline
\end{tabular}

C, D, E \& H= Physical variables, $-1=$ low level of the variable, $0=$ medium level of the variable $\&+1=$ high level of the variable.

The probability value of the interactions $\mathrm{CD}$, $\mathrm{CH}, \mathrm{DE}$ and $\mathrm{EH}$ are $0.3771,0.3114,0.2416$ and 0.3950 indicating that $62.3 \%, 68.9 \%, 75.8 \%$, and $60.5 \%$, respectively of the model was affected by these interactions, so their 3D diagrams are quietly horizontal and 2D contour plots are quietly regular (Fig. 6a,c,d,f). Whereas, the 3D response surface of the interaction $\mathrm{CE}$ exhibits perfect horizontal and perfect regular $2 \mathrm{D}$ contour plot as the $\mathrm{p}$-value is less than 0.0001 (highly significant), (Fig. 6b). This indicates that $99.99 \%$ of the model affected by this interaction.
On the contrary, Fig. 6e represents the interaction between inoculum size (D) and agitation speed $(\mathrm{H}), \mathrm{p}$-value $=0.8527$, indicating that only $14.73 \%$ of the model was affected by this interaction. Therefore, it demonstrated a bad interaction, irregular contour and crooked 3D response surface diagrams. The obtained results are in accordance with Fan et al. (2015) who reported that RSM represents a mathematical and statistical method to optimize an operational condition that is influenced by some independent variables in order to acquire the maximum yield through a cost-efficient procedure. 
TABLE 5. Statistical analysis of variance of CCD design for lipase activity by $R$. oryzae R1.

\begin{tabular}{|c|c|c|c|c|c|}
\hline Variable & df & $\begin{array}{c}\text { Mean } \\
\text { Square }\end{array}$ & Coefficients & F-value & $\begin{array}{c}\text { p-value } \\
(\text { Prob }>\text { F })\end{array}$ \\
\hline Model & 14 & 3853.85 & 137.24 & 1818.35 & $<0.0001^{*}$ \\
\hline C- Incubation temperature & 1 & 47155.21 & -51.18 & 22249.04 & $<0.0001 *$ \\
\hline D- Inoculum size & 1 & 163.81 & -3.02 & 77.29 & $<0.0001 *$ \\
\hline E- Incubation period & 1 & 5810.42 & 17.97 & 2741.51 & $<0.0001 *$ \\
\hline H- Agitation speed & 1 & 379.96 & 4.59 & 179.28 & $<0.0001^{*}$ \\
\hline $\mathrm{CD}$ & 1 & 1.76 & -0.33 & 0.83 & 0.3771 \\
\hline $\mathrm{CE}$ & 1 & 141.02 & -2.97 & 66.53 & $<0.0001 *$ \\
\hline $\mathrm{CH}$ & 1 & 2.33 & 0.38 & 1.10 & 0.3114 \\
\hline $\mathrm{DE}$ & 1 & 3.15 & -0.44 & 1.49 & 0.2416 \\
\hline $\mathrm{DH}$ & 1 & 0.076 & -0.069 & 0.036 & 0.8527 \\
\hline EH & 1 & 1.63 & 0.32 & 0.77 & 0.3950 \\
\hline $\mathrm{C}^{2}$ & 1 & 1.32 & 0.71 & 0.62 & 0.4421 \\
\hline $\mathrm{D}^{2}$ & 1 & 106.59 & 6.41 & 50.29 & $<0.0001 *$ \\
\hline$E^{2}$ & 1 & 9.99 & 1.96 & 4.72 & $0.0463^{*}$ \\
\hline $\mathrm{H}^{2}$ & 1 & 258.36 & -9.99 & 121.90 & $<0.0001 *$ \\
\hline Residual & 15 & 2.12 & & & \\
\hline Lack of Fit & 10 & 3.18 & & & \\
\hline Pure Error & 5 & 0.000 & & & \\
\hline Std. Dev. & & & 1.46 & & \\
\hline Mean & & & 136.71 & & \\
\hline C.V. \% & & & 1.06 & & \\
\hline $\mathrm{R}^{2}$ & & & 0.999 & & \\
\hline
\end{tabular}

a)

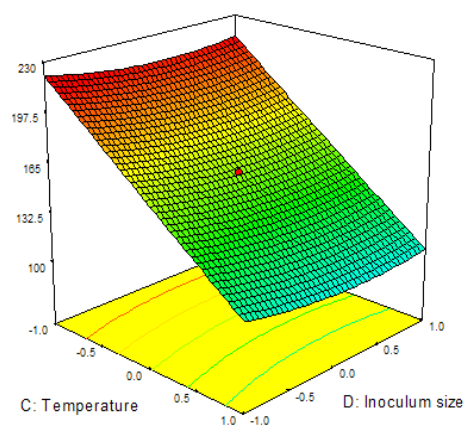

c)

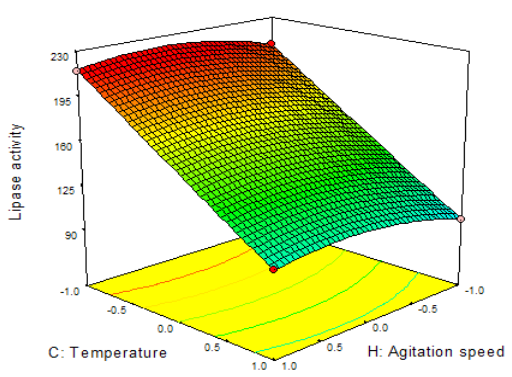

b)

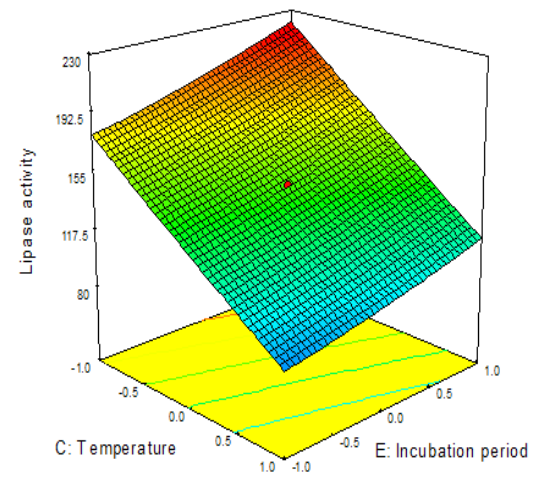

d)

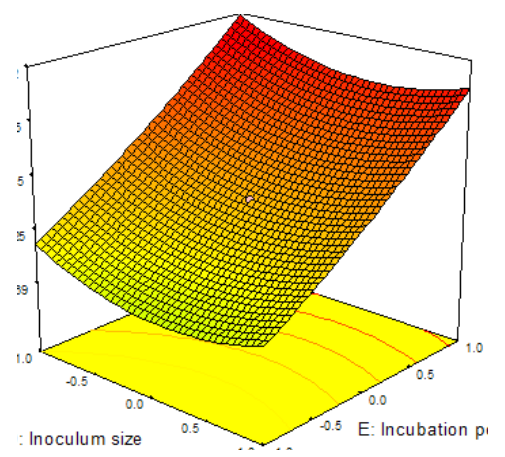


e)

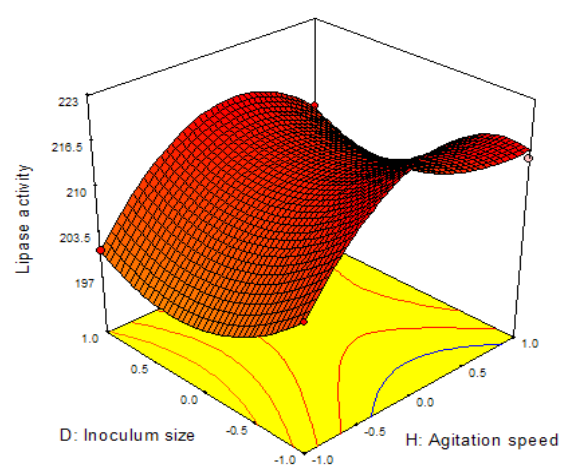

f)

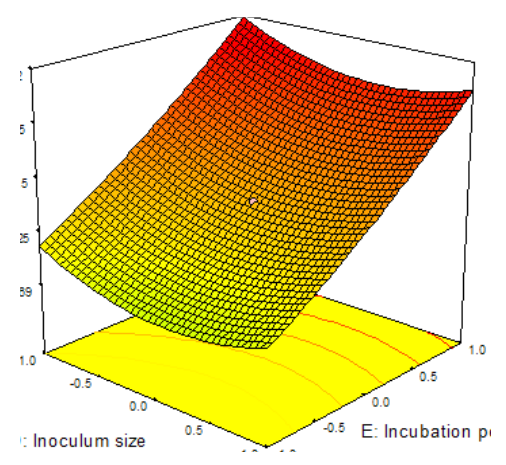

Fig. 6. Three-dimensional response surface plots showing the effect of temperature, inoculum size, incubation period and agitation speed on lipase activity. a) Temperature vs. inoculum size at agitation speed 125 rpm and 4 days of incubation period, b) Temperature vs. incubation period at agitation speed $125 \mathrm{rpm}$ and $8 \%$ inoculum size, c) Temperature vs. agitation speed at $8 \%$ inoculum size and 4 days of incubation period, d) Inoculum size vs. incubation period at $28^{\circ} \mathrm{C}$ and agitation speed $125 \mathrm{rpm}$, e) Inoculum size vs. agitation speed at $28^{\circ} \mathrm{C}$ and 4 days of incubation period, and f) Incubation period vs. agitation speed at $28^{\circ} \mathrm{C}$ and $8 \%$ inoculum size.

\section{Conclusion}

In this study, one variable at a time approach was used to select the optimum conditions for lipase production by Rhizopus oryzae R1. Results indicated $1 \%$ fish-frying oil, mixture of peptone and yeast extract at $\mathrm{pH} 5,8 \% \mathrm{v} / \mathrm{v}$ of fungal inoculum and 4 days of incubation period at $30^{\circ} \mathrm{C}$ attained the maximum activity. Out of ten variables, those with highly significance were optimized via Plackett-Burman design followed by response surface methodology. The highest lipase activity $(216.2 \mathrm{U} / \mathrm{mL})$ was predicted through central composite design.

\section{References}

Abada, E.A.E. (2008) Production and characterization of a mesophilic lipase isolated from Bacillus stearothermophilus AB-1. Pak. J. Biol. Sci. 11, 1100-1106.

Akhnazarova, S. and Kefarov, V. (1982) "Experiment Optimization in Chemistry and Chemical Engineering,"Mir Publishers, Moscow.

Amin, M. and Bhatti, H.N. (2014) Effect of physicochemical parameters on lipase production by Penicillium fellutanum using canola seed oil cake as substrate. Int. J. Agri. Biol. 16, 118-124.

Barnett, H.L. and Hunter, B.B. (1998) "Illustrated Genera of Imperfect Fungi," $4^{\text {th }}$ ed, APS Press.

Böhm, A. and Boos, W. (2004) Gene regulation in prokaryotes by subcellular relocalization of transcription factors. Curr. Opin. Microbiol. 7, 151156.

Bueno, P.R.M., de Oliveira, T.F., Caliari, M., Castiglioni, G.L. and Júnior, M.S.S. (2014) Selection and optimization of extracellular lipase production using agro-industrial waste. Afr. J. Biotechnol. 13(4), 566-573.

Carvalho, A.K.F., Faria, E.L.P., Rivaldi, J.D., Andrade, G.S.S., Oliveira, P.C. and Castro, H.F. (2015) Performance of whole-cells lipase derived from Mucor circinelloides as a catalyst in the ethanolysis of non-edible vegetable oils under batch and continuous run conditions. Ind. Crops Prod. 67, 287-294.

Colak, A., Kolcuoglu, Y., Faiz, Ö., Özen, A. and Dincer, B. (2007) Comparative characterization of diphenolases from two mulberry fruits (Morus alba L and Morus nigra L). Asian J. Chem. 19, 29612972.

Colen, G., Junqueira, R.G. and Moraes-Santos, T. (2006) Isolation and screening of alkaline lipaseproducing fungi from Brazilian savanna soil. World J. Microbiol. Biotechnol. 22, 881-885.

Colin, V.L., Baigori, M.D. and Pera, L.M. (2010) Effect of environmental conditions on extracellular lipases production and fungal morphology from Aspergillus niger MYA 135. J. Basic Microbiol. 50, 52-56. 
Colla, L.M., Primaz, A.L., Benedetti, S., Loss, R.A., Lima, M., Reinehr, C.O., Bertolin, T.E and Costa, J.A.V. (2016) Surface response methodology for the optimization of lipase production under submerged fermentation by filamentous fungi. Braz. J. Microbiol. 47, 461-467.

Dia, D. and Xia, L (2008) Enhanced production of Penicillium expansum PED-03 lipase through control of culture conditions and application of the crude enzyme in kinetic resolution of racemic allethrolone. J. Biotechnol. Prog. 21, 1165-1168.

Difco Manual (1998) "Dehydrated Culture Media and Reagents for Microbiology", $11^{\text {th }}$ ed, Detroit M. (Ed), Difco Laboratories, Division of Becton Dickinson and Company, Sparks, Maryland 21152, USA.

Falony, G., Armes, J.C., Mendoze, D. and Hernandez, J.L.M. (2006) Production of extracellular lipase from Aspergillus niger by solid-state fermentation. Food Technol. Biotech. 44, 235-240.

Fan, T., Hu, J., Fu, L. and Zhang, L. (2015) Optimization of enzymolysis-ultrasonic assisted extraction of polysaccharides from Momordica charabtia L by response surface methodology. Carbohyd. Polym. 115, 701-706.

Freire, G.D.M. and Castilho, F.L. (2008) Lipases em Biocatalise. In: Enzimas em Biotecnologia: Producao, Aplicacao e Mercado," Bon, E.P.S., Corvo, M.L. and Ferrara, M.A. (Ed), Interciencia, Rio de Janeiro, Brazil.

Gomes, F.M., Paula, A.V., Silva, G.S. and Castro, H.F. (2006) Determinacao das propriedades cataliticas em meio aquoso e organico da lipase de Candida rugosa imobilizada em celulignina quimicamente modificada por carbonildiimidazol. Quimica Nova 29(4), 710-718.

Huang, C., Zong, M.H., Wu, H. and Liu, Q.P. (2009) Microbial oil production from rice straw hydrolysate by Trichosporon fermentans. Bioresour. Technol. 100, $4535-4538$.

Iftikhar, T., Niaz, M., Afzal, M., Ul-Haq, I. and Rajoka, M.I. (2008) Maximization of intracellular lipase production in a lipase-overproducing mutant derivative of Rhizopus oligosporus DGM 31: A kinetic study. Food Technol. Biotech. 46(4), 402402.

Egypt. J. Micro. Vol. 52 (2017)
Imandi, S.B., Karanam, S.K. and Garapati, H.R. (2013) Use of Plackett-Burman design for rapid screening of nitrogen and carbon sources for the production of lipase in solid state fermentation by Yarrowia lipolytica from mustard oil cake (Brassica napus). Braz. J. Microbiol. 44, 915-921.

Kakde, R.B. (2011) Extracellular lipase enzyme production by seed-borne fungi under the influence of physical factors. Int. J. Biol. 3(1), 94-100.

Kaushik, R., Saran, S., Isar, J. and Saxena, R.K. (2006) Statistical optimization of medium components and growth conditions by response surface methodology to enhance lipase production by Aspergillus carneus. J. Mol. Catal. B-Enzym. 40, 121-126.

Kiran, G.S., Shanmughapriya, S., Jayalakshmi, J., Selvin, J., Gandhimathi, R., Sivaramakrishnan, S., Arunkumar, M., Thangavelu, T. and Natarajaseenivasan, K. (2008) Optimization of extracellular psychrophilic alkaline lipase produced by marine Pseudomonas sp. (MSI057). Bioprocess Biosyst. Eng. 31(5), 483-492.

Knudsen, B., Knudsen, T., Flensborg, M., Sandmann, H., Heltzen, M., Andersen, A., Dickenson, M., Bardram, J., Steffensen, P.J., Mønsted, S., Lauritzen, T., Forsberg, R., Thanbichler, A., Bendtsen, J.D., Görlitz, L., Rasmussen, J., Tordrup, D., Værum, M., Ravn, M.N., Hachenberg, C., Fisker, E., Dekker, P., Schultz, J., Hein, A.K. and Sinding, J.B. (2009) CLC Main Workbench software version 5.5, CLC bio A/S, Denmark.

Lima, V.M.G., Krieger, M.I.M., Sarquis, D.A., Mitchell, L.P. and Ramos, J.D. (2003) Effect of the nitrogen and carbon sources on lipase production by Penicillium aurantiogriseum. Food Technol. Biotech. 41, 105-110.

Maia, M.M.D., Morais, M.M.C., Morais, M.A., Melo, E.H.M. and Filho, J.L.L. (1999) Production of extracellular lipase by the phytopathogenic fungus Fusarium solani FS1. Rev. Microbiol. 30, 304-309.

Mohan, T.S., Palavesam, A. and Immanvel, G. (2008) Isolation and characterization of lipase-producing Bacillus strains from oil mill waste. Afr. $J$. Biotechnol. 7(15), 2728-2735.

Morais, M.M.C., Melo, E.H.M., Morais, M.A. and Filho, J.L.L. (1998) Production of extracellular 
lipase by a Candida rugosa strain isolated in Pernambuco. Rev. Microbiol. 29(2), 134-137.

Nagarajan, S. (2012) New tools for exploring "old friends microbial lipases". Appl. Biochem. Biotechnol.168, 1163-1196.

Niaz, M., Iftikhar, T., Qureshi, F.F. and Niaz, M. (2014) Extracellular lipase production by Aspergillus nidulans (MBL-S-6) under submerged fermentation. Int. J. Agri. Biol. 16, 536-542.

Oliveira, T.F., Hidálgo, M.R. and Júnior, M.S.S. (2014) Production of lipase extracted from aqueous waste: Enzymatic activity kinetics. Ciênc. Agrotec. 38(6), $562-572$.

Patil, K.J. and Mahajan, R.T. (2011) Lipase biodiversity. Indian J. Sci. Technol. 4(8), 971-982.

Plackett, R.L. and Burman, J.P. (1946) The design of optimum multifactorial experiments. Biometrika 33, 305-325.

Prabhakar, T., Kumar, K.A. and Ellaiah, P. (2002) The effect of cultural conditions on the production of lipase by fungi. J. Sci. Ind. Res. 61, 123-127.

Prazeres, J.N., Cruz, J.A.B. and Pastore, G.M. (2006) Characterization of alkaline lipase from Fusarium oxysporum and the effect of different surfactants and detergents on the enzyme activity. Braz. J. Microbiol. 37, 505-509.

Reshma, C.H. and Shanmugam, D.P. (2013) Isolation and characterization of the lipase from Aspergillus brasiliensis. Int. J. Biotechnol. Bioeng. Res. 4(5), 481486.

Rodrigues, C., Cassini, S.T.A., Antunes, P.W.P., Pinotti, L.M., Keller, R.P. and Gonçalves, R.F. (2015) Lipase and surfactant production by fungi isolated of oily residues of environmental sanitation in liquid and solid phase reactors. Int. J. Appl. Sci. Technol. 5(3), 46-54.

Rodrigues, M.I. and Iemma, A.F. (2014) Experimental design and process optimization, CRC Press, New York, USA.

Roveda, M., Hemkemeier, M. and Colla, L.M. (2010) Evaluation of lipase production using different strains of microorganisms isolated from dairy effluent through submerged fermentation. Food Sci. Technol. 30(1), 126-131.
Salihu, A., Alam, M.Z., Abdulkarim, M.I. and Salleh, H.M. (2012) Lipase production: as insight in the utilization of renewable agricultural residues. Resour. Conserv. Recy. 58, 36-44.

Singh, R., Gupta, N., Goswami, V.K. and Gupta, R. (2006) A simple activity staining protocol for lipases and esterases. Appl. Microbiol. Biotechnol. 70, 679-682.

Stockar, U., Maskow, T., Liu, J., Marison, I.W. and Patino, R. (2006) Thermodynamics of microbial growth and metabolism: An analysis of the current situation. J. Biotechnol. 121, 517-533.

Supakdamrongku, P., Bhumiratana, A. and Wiwat, C. (2010) Characterization of an extracellular lipase from the biocontrol fungus, Nomuraearileyi MJ, and its toxicity toward Spodopteralitura. J. Invertebr. Pathol. 105(3), 228-235.

Sutton, D.A., Fothergill, A.W. and Rinaldi, M.G. (1998) "Guide to Clinically Significant Fungi." Lippincott Williams \& Wilkins, Baltimore, Philadelphia, USA.

Tanyildizi, M.S., Özer, D. and Elibol, M. (2005) Optimization of $\alpha$-amylase production by Bacillus sp. using response surface methodology. Process Biochem. 40, 2291-2296.

Teng, Y. and Xu, Y. (2008) Culture condition improvement for whole cell lipase production in submerged fermentation by Rhizopus chinensis using statistical method. Bioresour. Technol. 99(9), 3900-3907.

Ulker, S., Ozel, A., Colak, A.Ş. and Karaoğlu, A. (2010) Isolation, production and characterization of an extracellular lipase from Trichoderma harzianum isolated from soil. Turk. J. Biol. 35, 543-550.

Vasiee, A., Behbahani, B. A., Yazdi, F. T. and Moradi, S. (2016) Optimization of the production conditions of the lipase produced by Bacillus cereus from rice flour through Plackett-Burman Design (PBD) and response surface methodology (RSM). Microb. Pathogen. 101, 36-43.

Veerapagu, M., Narayanan, D.A.S., Ponmurugan, K. and Jeya, K.R. (2013) Screening selection identification production and optimization of bacterial lipase from oil-spilled soil. Asian. J. Pharm. Clin. Res. 6, 62-67. 
Wang, D., Xu, Y. and Shan, T. (2008) Effects of oils and oil-related substrates on the synthetic activity of membrane-bound lipase from Rhizopus chinensis and optimization of the lipase fermentation media. Biochem. Eng. J. 41(1), 30-37.
Willerding, A.L., de Oliveira, L.A., Moreira, F.W., Germano, M.G. and Chagas, A.F. (2011) Lipase activity among bacteria isolated from Amazonian soils. Enzym. Res. 1-5.

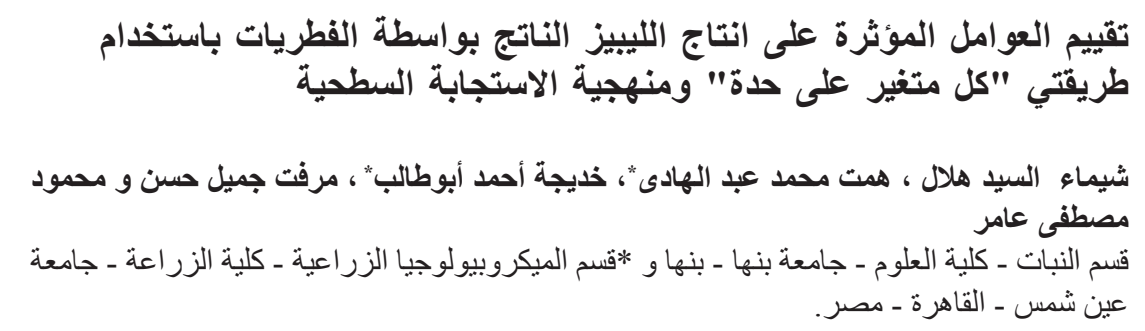

هذا البحث يهذف إلى تحسين العو امل المؤثرة على انتاج الليبيزفي البيئة السائلة. وتم تعريف أكفأ عزلة لئلة

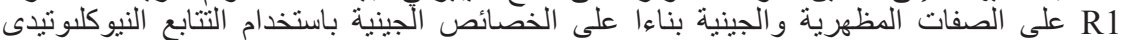

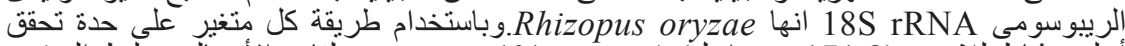

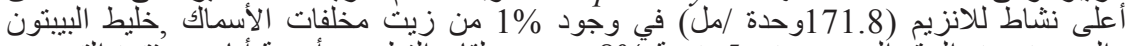

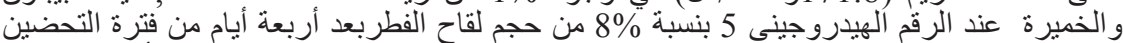

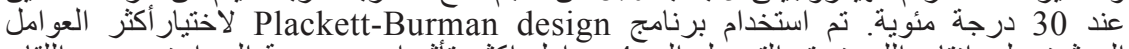

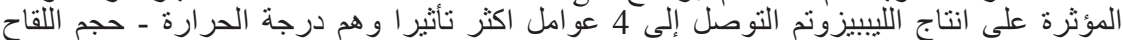

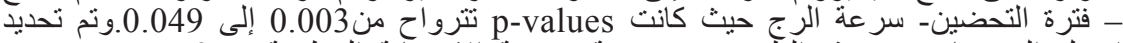

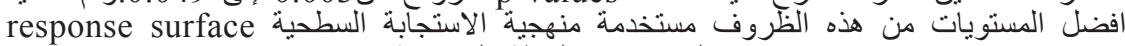
central composite design معتمدا على تصميم النقطة المركزية الإكية (methodology (RSM (CCD درجة حر ارة 28 درجة مئوية وسرعة الرئ الرج حوالى 150 لفة لكل دقيقة لمدة 4 أيام. 